\title{
EXPERIMENTAL INVESTIGATIONS OF A SOLAR PARABOLIC TROUGH COLLECTOR FOR CIRCULAR AND ELLIPTICAL ABSORBER
}

\author{
Suresh. $R^{1^{*}}$, Subash Chandra Bose. $R^{2}$,Arumugam. $K^{3}$, Anbazhagan. $R^{4}$, Sathiyamoorthy. $V^{5}$ \\ Nagendran.N.A ${ }^{6}$, Prakash. ${ }^{7}$ \\ ${ }_{1,4,5}$ Associate Professor , ${ }^{3}$ Professor,,${ }^{6,7}$ Assistant Professor \\ Department of Mechanical Engineering \\ Vel Tech High Tech Dr.Rangarajan Dr.Sakunthala Engineering. College, Tamilnadu, India \\ ${ }^{2}$ Principal, Sun Engineering college,Nagercoil,Tamilnadu,India. \\ * Corresponding Author E-mail: sureshr77@gmail.com
}

\section{ABSTRACT}

Solar parabolic trough collector is one of the most efficient and an effective technology to deal with environmental pollution and it has gained much attention due to the recent energy demand. The solar parabolic trough collector is one of the most promising techniques for absorbing the heat from the sun. This heat is utilized for electricity generation and other industrial heating applications. This paper describes the theoretical and experimental assessment of performance of the circular and elliptical absorbers used in solar parabolic trough collector. The absorber tube of parabolic trough collector is used to transfer the heat to the working fluid. The working fluid considered over here is water which is the best operating medium in direct steam generation. The mass flow rate of water in absorber tube is analyzed in 3 stages as $0.016,0.024$ and $0.030 \mathrm{~kg} / \mathrm{s}$ respectively. The experimental test is done in Chennai-Tamilnadu, Southern part of India which experiences a superior temperature throughout the year. The experiment is conducted for the period of one year from June 2015 to May 2016. The performance improvement focuses on collector efficiency, useful heat transfer rate, outlet temperature of working fluid, temperature gradient, overall heat transfer rate and the thermal losses.

Keywords: Solar Parabolic Collector, Elliptical heat absorber, heat flux, Collector efficiency, heat transfer rate.

\section{INTRODUCTION}

In the recent decades solar energy with the advancement in technology became the best energy resource for reducing the power demand from the non-renewable sources like coal, petroleum products etc. Currently the energy crisis has made a steep decrease in industrial development and commercial life of increasing populations. Most of the countries which extract power from solar energy uses Parabolic Trough Collector (PTC) device. The parabolic trough collector lies on the concentrated type device with a range of thermal energy absorption of about $400^{\circ} \mathrm{C}$, hence used for electricity generation by steam power cycle [1]. The parabolic trough collector has a receiver where heat transferring fluids like water or oil or some organic fluid circulates. The receiver is generally placed at the focus of the parabola. Since India being a tropical country it receives high solar insolation. Many works has been carried by many researchers on PTC for effective utilization of energy by optimization, thermal analysis, numerical analysis etc.

Experimental investigation has been done on the receiver, with black epoxy coated receiver and the work carried with and without glass cover on the receiver.The concluded result shows that the instantaneous collector efficiency has been increased [2]. Direct steam generation method in the absorber tube is also an important process used in electricity generation, but the superheated steam causes overheating on the absorber tube and result in non-homogeneous heat flux so the absorber tube performance should be pondered [3].

The thermal analysis on the modified receiver with porous disc receiver in parabolic collector when tested for different collector orientation angle also by varying height and width of disc has made some changes by exhibiting different heat flux. The use of porous disc receiver shows better performance [4]. Obviously the receiver is also provided with internal helically finned tubes for reducing the thermal losses also to minimize thermo mechanical stress and thermal fatigue, considerably the parabolic trough solar plant efficiency has also increased by $3 \%$ resulting in escalation of 20.6MW electricity production [5]. Solar parabolic trough collector is also studied with the heat transferring fluid as the gasphase nano fluids ( $\mathrm{CuO}$ and $\mathrm{Ni}$ nano particles), resulting an increase in the heat exchange surface which leads to the improvement in thermal efficiency by $62.5 \%$ and the temperature of the nano fluid outlet as $650^{\circ} \mathrm{C}$ [6].

Michael Geyer and Eckhard Lupfert have proposed and experimentally constructed Euro Trough (ET) parabolic collector ET100 and ET150 for high performance with the standard receiver and reflecting mirror panel. They also added a finite element analysis validation with their experimental work and concluded that their proposed system has reduced weight and cost reduction [7]. The Solar Parabolic Trough Collector (SPTC) is also used as small scale field in hotels for hot water generation by adding some modification as fiber reinforced plastic parabolic trough collector which has less weight and have the capacity to keep the food stuffs in hot condition, they have also done a cost analysis over the outmoded electricity method and clinched as SPTC as economical [8].

Thermal losses on the absorber tube are also a major problem and much research work has been done with the SPTC power plant. Yaghoubi etal. have done a numerical simulation using the experimentally measured data from 250 kW Shiraz (Iran) solar power plant. Authors have done a study with three types of absorber tubes, i) vacuum ii) lost vacuum (air) iii) broken glass tube (bare). They finalized that the use of absorber tube with vacuum reduces the thermal losses compared to other types and also stated that the poor isolation leads to thermal efficiency losses in solar thermal power plant [9]. Many studies have been done and are still on progress about the numerical simulation of absorber tube $6348 \mid \mathrm{P}$ a g e 
using finite element method and finite volume method. Changfu You et al. have done a heat transfer model of absorber considering flow study using finite element method for direct steam generation plant with a conclusion that the solar radiation fluctuation drastically affects the operation of SPCT for direct steam generation [10]. Finite Volume Method (FVM) is also employed in direct steam generation thermal plant, for improving the heat transfer rate in absorber computational fluid dynamics study has been done and the results are evaluated with the experimental value [11]. Hachicha et al. have also studied about the effect of solar flux around the SPTC using FVM and solar ray trace technique by considering the size of sun [12]. The wind load in SPTC is also taken into account by many studies, where the wind is one of the major problems causing parameter. The wind velocity can damage the solar tracking method and change the focus point of SPTC which results in the poor heat transfer by the absorber. Naeeni et al. have studied the effect of wind load for scrutinizing the performance of solar collector and absorber by varying the orientation angle from $90^{\circ}, 60^{\circ}, 30^{\circ}, 0^{\circ}$, $30^{\circ},-60^{\circ}$ and $-90^{\circ}$ of parabolic collector, specifically they also considered the effect of wind along the absorber [13]. Hence the various studies have been done on the performance improvement on absorber of SPTC for various purposes like heating applications and mainly for power generation. In this present study elliptical absorber was designed, constructed and investigated theoretically and experimentally under different water mass flow rate and inlet water temperature.

\section{Experimental Specifications}

The set up consists of solar parabolic trough collector with a storage tank of 70 liter capacity, non-return valve for maintaining the flow direction and control valve for regulating the water flow rate. To obtain the measurement data's the following measuring instruments are attached namely, pyranometer, anemometer, flow meter and thermocouple with digital display. The pyranometer is used for measuring the solar radiation in the apparatus, digital anemometer for measuring the wind velocity, flow meter for measuring the mass flow rate of water and the thermocouple with digital display for temperature measurement. The basic parameters of parabolic trough collector and the designed elliptical absorber dimensions are shown in table 1.

Table 1: Design specifications of elliptical absorber tube of parabolic trough collector

\begin{tabular}{|l|l|}
\hline Working Fluid & Water \\
\hline Major axis of elliptical absorber (a) & $26 \mathrm{~mm}$ \\
\hline Minor axis of elliptical absorber (b) & $16.7 \mathrm{~mm}$ \\
\hline Thickness of absorber tube (t) & $2 \mathrm{~mm}$ \\
\hline Outer diameter of glass tube (Do) & $58 \mathrm{~mm}$ \\
\hline Aperture of the concentrator (W) & $1200 \mathrm{~mm}$ \\
\hline Intercept factor & 0.95 \\
\hline Length of Parabolic trough & $1500 \mathrm{~mm}$ \\
\hline Inner diameter of glass tube & $50 \mathrm{~mm}$ \\
\hline Glass cover transitivity for solar radiation (T) & $85 \%$ \\
\hline Emissivity of glass $(\varepsilon)$ & 0.82 \\
\hline Concentration ratio & $13.69: 1$ \\
\hline Collector aperture area & $1.8 \mathrm{~m}^{2}$ \\
\hline Absorber tube emissivity & 0.15 \\
\hline
\end{tabular}

\section{EXPERIMENTAL SETTING}

The experiment work has been done for a period of one year (from June 2015 to May 2016) and on every month the test was conducted for three sunny days with the normal circular absorber and another three days with the elliptically designed and constructed absorber. The test was recorded on hourly basis. In this experiment the cold water from the storage tank is passed through the absorber tube in solar parabolic trough collector via gravity method, because the storage tank is kept above the level of collector, and the heated water again enters the storage tank through the nonreturn valve. The flow of hot water takes place by thermo siphon (natural circulation) and hence the hot water is replaced by the cold water from the bottom of the storage tank. The measurement data's such as the total solar radiation on the collector, wind velocity, water mass flow rate and the temperatures at inlet, outlet and the ambient temperatures are noted for every one hour. The temperature on the outer cover of the glass tube was also noted. Similarly the experiment is repeated with the elliptical absorber tube and all the readings were recorded. In this experimental set up the sun tracking mechanism has been attached hence the set up tilts from east to west automatically. The mass flow rate of water maintained for the test was $0.016,0.024$ and $0.030 \mathrm{~kg} / \mathrm{s}$. The layout of the experimental setup is shown in Fig. 1 . 


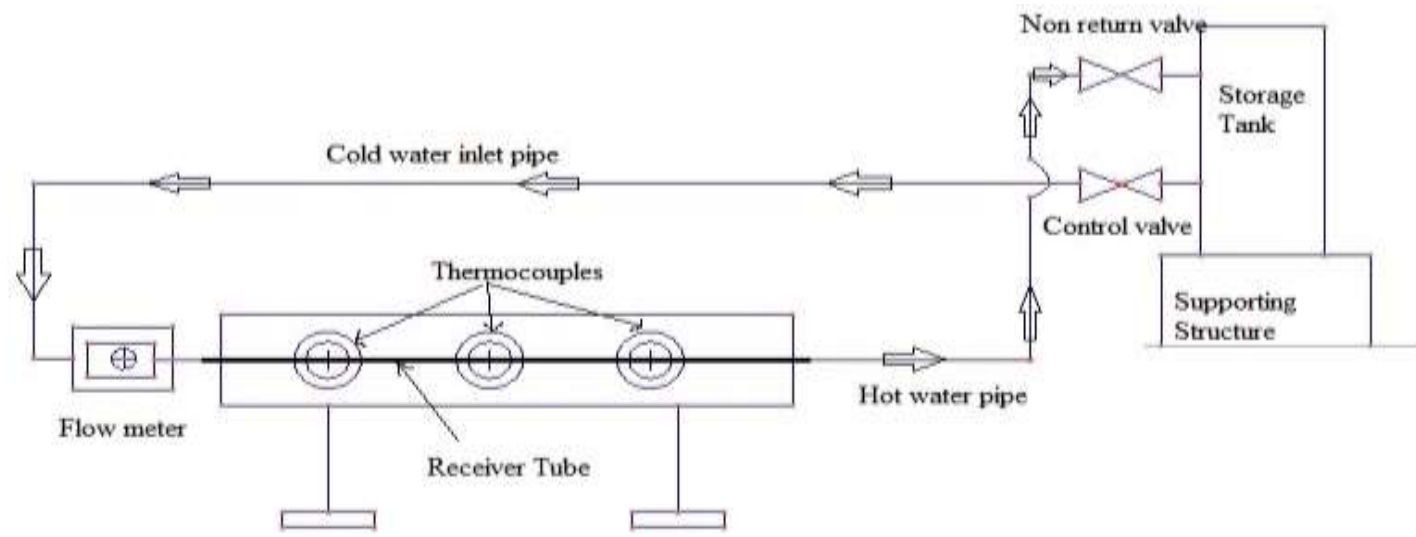

Fig.1 Layout of Experimental Setup

Table 2: Average experimental readings during June 2015 to May 2016 for circular absorber with mass flow rate of $0.016 \mathrm{~kg} / \mathrm{s}$

\begin{tabular}{|c|c|c|c|c|c|c|}
\hline $\begin{array}{l}\text { Sl. } \\
\text { No }\end{array}$ & Time & $\begin{array}{c}\text { Ambient } \\
\text { Temperature } \\
{ }^{\circ} \mathrm{C}\end{array}$ & $\begin{array}{c}\text { Inlet Water } \\
\text { Temperature } \\
{ }^{\circ} \mathrm{C}\end{array}$ & $\begin{array}{l}\text { Outlet Water } \\
\text { Temperature } \\
{ }^{\circ} \mathrm{C}\end{array}$ & $\begin{array}{l}\text { Total solar Radiation on } \\
\text { collector }\left(\mathrm{W} / \mathrm{m}^{2}\right)\end{array}$ & $\begin{array}{l}\text { Wind Speed } \\
(\mathrm{m} / \mathrm{s})\end{array}$ \\
\hline 1 & 10.00 & 30 & 26 & 30 & 821 & 3.2 \\
\hline 2 & 11.00 & 32 & 28 & 35 & 882 & 3.6 \\
\hline 3 & 12.00 & 36 & 30 & 44 & 937 & 4.1 \\
\hline 4 & 13.00 & 38 & 32 & 50 & 968 & 3.4 \\
\hline 5 & 14.00 & 40 & 32 & 58 & 912 & 3.6 \\
\hline 6 & 15.00 & 37 & 32 & 55 & 892 & 3.5 \\
\hline 7 & 16.00 & 34 & 33 & 53 & 867 & 3.8 \\
\hline
\end{tabular}

Table 3: Average experimental readings during June 2015 to May 2016 for elliptical absorber with mass flow rate of $0.016 \mathrm{~kg} / \mathrm{s}$

\begin{tabular}{|c|c|c|c|c|c|c|}
\hline $\begin{array}{l}\text { Sl. } \\
\text { No }\end{array}$ & Time & $\begin{array}{c}\text { Ambient } \\
\text { Temperature } \\
{ }^{\circ} \mathrm{C}\end{array}$ & $\begin{array}{c}\text { Inlet Water } \\
\text { Temperature } \\
{ }^{\circ} \mathrm{C}\end{array}$ & $\begin{array}{c}\text { Outlet Water } \\
\text { Temperature } \\
{ }^{\circ} \mathrm{C}\end{array}$ & $\begin{array}{l}\text { Total solar Radiation on } \\
\text { collector }\left(\mathrm{W} / \mathrm{m}^{2}\right)\end{array}$ & $\begin{array}{l}\text { Wind Speed } \\
(\mathrm{m} / \mathrm{s})\end{array}$ \\
\hline 1 & 10.00 & 29 & 28 & 34 & 883 & 4.0 \\
\hline 2 & 11.00 & 32 & 31 & 48 & 912 & 3.8 \\
\hline 3 & 12.00 & 37 & 35 & 55 & 983 & 3.9 \\
\hline 4 & 13.00 & 38 & 37 & 61 & 1002 & 3.3 \\
\hline 5 & 14.00 & 41 & 40 & 59 & 996 & 3.5 \\
\hline 6 & 15.00 & 38 & 38 & 56 & 926 & 3.8 \\
\hline 7 & 16.00 & 35 & 33 & 54 & 890 & 4.2 \\
\hline
\end{tabular}

The table 2 and 3 illustrates the average variation of temperature and solar radiations for the mass flow rate of $0.014 \mathrm{~kg} / \mathrm{s}$, which are measured directly using thermocouples and pyranometer. It shows a successive improvement in final temperature which leads to a better absorption of solar radiation. Similarly the test was conducted using a different mass flow rate of about 0.024 , and $0.030 \mathrm{~kg} / \mathrm{s}$ results in improved heat absorption by the elliptical absorber

\section{THEORETICAL METHODOLOGY}

The thermal performance of the solar parabolic trough collector is based on the heat transfer rate of the absorber. The useful energy obtained for the collector is calculated using the following equations, $[14,16]$

$$
\begin{aligned}
& \mathrm{Q}_{\mathrm{u}}=\mathrm{mC}_{\mathrm{p}}\left(\mathrm{T}_{\text {out }}-\mathrm{T}_{\text {in }}\right) \\
& \mathrm{Q}_{\mathrm{u}}=\mathrm{mC}_{\mathrm{p}}\left\{\frac{c s}{u_{l}}+T_{\mathrm{amp}}-\mathrm{T}_{\text {in }}\right\}\left\{1-\exp \left[-\frac{F \pi\left(D_{h y d}+2\right) U L}{u_{l}}\right]\right\}
\end{aligned}
$$


Where,

$Q_{u} \quad=\quad$ Useful heat energy delivered from the aperture $(\mathrm{W})$

$\mathrm{m}=$ Mass flow rate, $\mathrm{kg} / \mathrm{s}$

$\mathrm{T}_{\text {out }} \quad=$ Outlet water temperature $\left({ }^{\circ} \mathrm{C}\right)$

$\mathrm{T}_{\text {in }} \quad=$ Inlet water temperature $\left({ }^{\circ} \mathrm{C}\right)$

$\mathrm{T}_{\mathrm{amp}}=$ ambient temperature $\left({ }^{\circ} \mathrm{C}\right)$

$\mathrm{C}_{\mathrm{p}} \quad=$ Specific heat of water, $\mathrm{kJ} / \mathrm{kg}{ }^{\circ} \mathrm{C}$

C = Concentration ratio

$\mathrm{S} \quad=$ Incident solar flux absorbed in the absorber plate, $\mathrm{W} / \mathrm{m}^{2}$

$\mathrm{U} \quad=$ Total heat loss coefficient, $\mathrm{W} / \mathrm{m}^{20} \mathrm{C}$

$\mathrm{F}=$ Collector efficiency factor,

$\mathrm{D}_{\text {hyd }} \quad=$ Hydraulic diameter of ellipse $(\mathrm{m})$

$\mathrm{L} \quad=$ Length of concentrator $(\mathrm{m})$

$\mathrm{W}=$ Width of parabolic reflector $(\mathrm{m})$

The useful heat transfer energy gained per unit of the collector length $\left(Q_{u}\right)$ can be expressed in terms of the local receiver temperature $\left(T_{m}\right)$ also known as absorber mean surface temperature,[14,16]

$$
\begin{aligned}
& \mathrm{Q}_{\mathrm{u}^{\prime}}=\frac{\mathrm{Q}_{\mathrm{u}}}{L} \\
& \mathrm{Q}_{\mathrm{u}^{\prime}}=\mathrm{F}\left\{\mathrm{S}-\frac{U_{l}}{c}\left(\mathrm{~T}_{\mathrm{m}}-\mathrm{T}_{\text {air }}\right)\right\}\left(\mathrm{W}-\left[\mathrm{D}_{\text {hyd }}+2\right]\right)
\end{aligned}
$$

Where, $F^{\prime}$ is the collector efficiency factor and can be defined from the equation $(6) \&(7)[14,16]$

$$
\begin{aligned}
& \mathrm{F}^{\prime}=\frac{1}{U}\left\{\frac{1}{U}+\frac{\mathrm{D}_{\text {hyd }}+2}{\mathrm{D}_{\text {hyd }} X h_{f}}\right\} \\
& \mathrm{Q}_{\mathrm{u}}=\mathrm{F}_{\mathrm{R}}\left\{\mathrm{W}-\left(\mathrm{D}_{\text {hyd }}+2\right)\right\} L\left[S-\frac{U}{C}\left\{\frac{c S}{u l}\left[T_{\text {in }}-\mathrm{T}_{\text {air }}\right]\right\}\right]
\end{aligned}
$$

Here $h_{f}=$ heat transfer coefficient on inside surface of tube $\left(W / \mathrm{m}^{2}{ }^{\circ} \mathrm{C}\right)$

$\mathrm{F}_{\mathrm{R}}=$ Collector heat removal factor

The collector heat removal factor is given by the following equation,

$$
\mathrm{F}_{\mathrm{R}}=\frac{\mathrm{mc}_{\mathrm{p}}}{\pi X\left(D_{\text {hyd }}+2\right) X L X U}\left[1-\exp \left\{-\frac{F^{\wedge} \pi\left(D_{\text {hyd }}+2\right) X U X L}{m C_{P}}\right\}\right]
$$

Hence the collector efficiency can be obtained by dividing useful heat transfer energy by the product of collector aperture area and $\mathrm{I}_{\mathrm{br}}$, and the instantaneous collection efficiency $\left(\eta_{\mathrm{in})}\right.$ can be calculated by the following equation $(9)[14,16]$

$$
\eta_{\text {in }} \quad=\frac{Q_{u}}{I b r W L}
$$

(i) Overall loss coefficient and heat co-relations:

The overall heat loss coefficient in the solar parabolic trough collector is based on the convection and radiation, and the heat loss rate per unit length is given by the following equation $(10 \& 11)[14,16]$

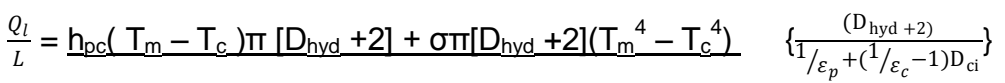

$\frac{q_{l}}{L}=h W\left(T_{m}-T_{a m p}\right) \pi D_{c o}+\sigma \pi D_{c o} \varepsilon_{c}\left(T_{c}^{4}-T_{a m p}{ }^{4}\right)$

Where,

$D_{c 0}=$ Diameter of the glass cover outer

$\mathrm{T}_{\mathrm{C}}=$ Temperature of cover $\left({ }^{\circ} \mathrm{C}\right)$

$h_{w}=$ Wind heat transfer coefficient, $W / m^{2} K$

$\varepsilon_{p}=$ Emissivity of absorber surface for long wavelength radiation

$\varepsilon_{\mathrm{C}=}$ Emissivity of cover surface for long wavelength radiation 
(ii) Rate of heat transfer coefficient between the elliptical absorber and glass cover:

The region between the elliptical absorber and the glass cover is maintained at vacuum condition. The rate of heat transfer coefficient $h_{p c}$ for the vacuum space can be calculated by the following equations (14 \&16)

$$
\frac{\mathrm{K}_{\mathrm{eff}}}{K}=0.317(\mathrm{Ra})^{0.25}
$$

The Rayleigh's number is given as,

$$
(\mathrm{Ra})^{0.25}=\frac{\ln \frac{D_{c i}}{(\mathrm{Dhyd}+2)}}{b^{0.75}\left(\frac{1}{(\mathrm{Dhyd}+2)^{0.6}}+\frac{1}{(\mathrm{D} \mathrm{ci})^{0.6}}\right.}
$$

Hence the rate of heat transfer coefficient for the enclosed space between elliptical absorber and glass cover is given as

$$
\mathrm{h}_{\mathrm{pc}}=\frac{2 \mathrm{~K}_{\text {eff }}}{(\text { Dhyd }+2) X \ln \left(\frac{D_{c i}}{(\text { Dhyd }+2)}\right.}
$$

(iii) Heat transfer coefficient on the inside surface of the elliptical absorber tube :

The heat transfer coefficient $h_{f}$ through the convective mode on the inside surface of the elliptical absorber tube is given by the following equation,

$$
\mathrm{N}_{\mathrm{u}}=\frac{\text { hy } \mathrm{D}_{\text {hyd }}}{K}
$$

Also for the Reynolds number greater than 2000 , the flow is turbulent and heat transfer coefficient may be given as

$$
\mathrm{N}_{\mathrm{u}} \quad=0.023 \operatorname{Re}^{0.8} \operatorname{Pr}^{0.4}
$$

\section{RESULTS AND DISCUSSION}

\subsection{Time of Day Vs Average Temperature}

The experimentally found result as shown in fig.2 reveals that the proposed system with the elliptical absorber has high heat transfer rate when compared to the ordinary circular absorber. The solar radiation is utilized maximum in the elliptical absorber resulting in better outlet temperature and comparatively high temperature gradient. The vacuum condition made between the absorber and the glass cover has reduced the thermal losses considerably, because the elliptical absorber has more contact area and the major amount of heat are carried away by the mass of water passing through the absorber.

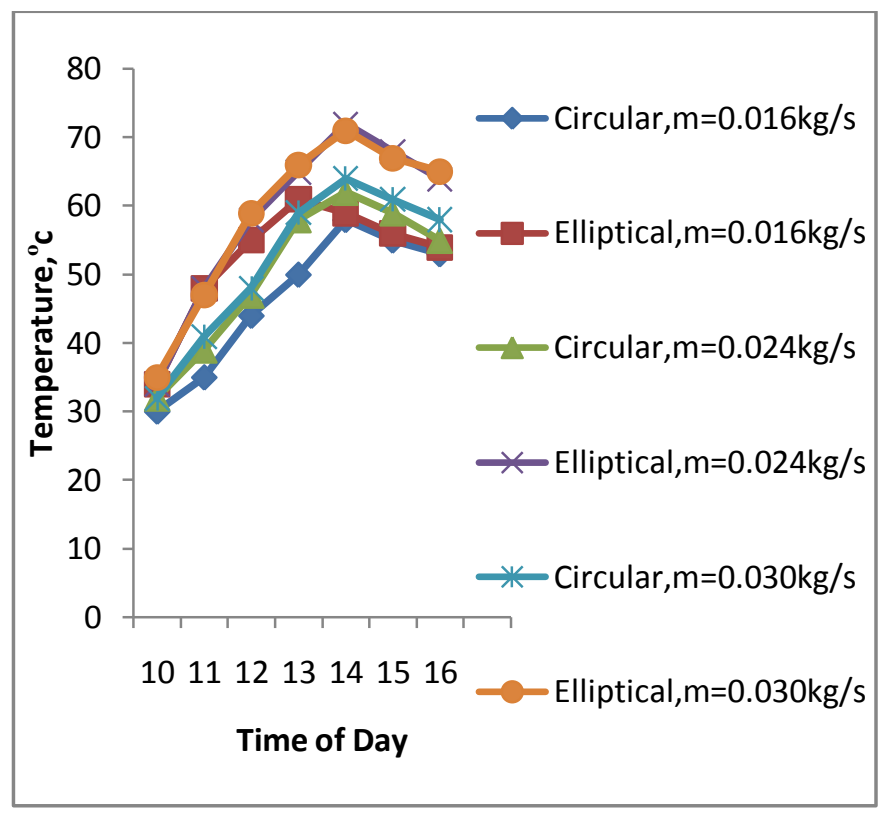

Fig. 2 Variation of Average Temperature with respect to time of Day

Similarly the experimental readings are calculated from June 2015 to May 2016. Since the October, November and December of 2015 became rainy season in Tamilnadu, hence not much efficiency is obtained. During those periods, the usage of elliptical absorber tube resulted with an average temperature range of about $64^{\circ} \mathrm{C}$ whereas the average temperature of normal circular absorber tube is about $55^{\circ} \mathrm{C}$ for the mass flow rate of $0.024 \mathrm{~kg} / \mathrm{s}$.

The variation of temperature for the elliptical and normal absorber for different mass flow rate during the hottest period of May 2016. It shows the performance of elliptical absorber in the PTC makes a significant effect on the working fluid hence resulting in the improvement in efficiency. 


\subsection{Time of Day Vs Average Solar Radiation}

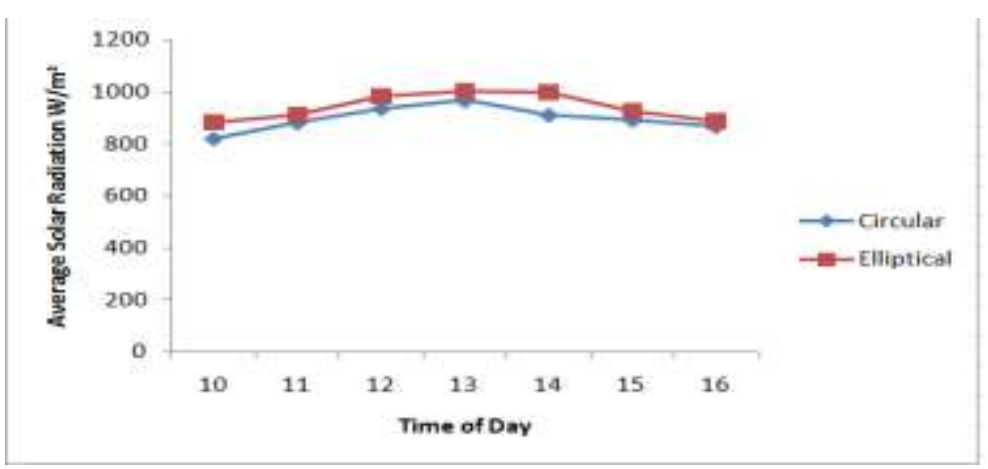

Fig. 3 Average Solar Radiation absorbed to Time of Day

The solar radiation absorbed with respect to time of day is shown in fig.3. The solar flux absorbed by the absorber in the form of sensible heat causes the working fluid to absorb more heat. The solar flux absorption is based on the surface exposed to the solar radiation, here in the elliptical absorber have more surface ie, the major axis of the ellipse is large when compared to the normal absorber.

\subsection{Months of Year Vs Average Overall Heat Loss}

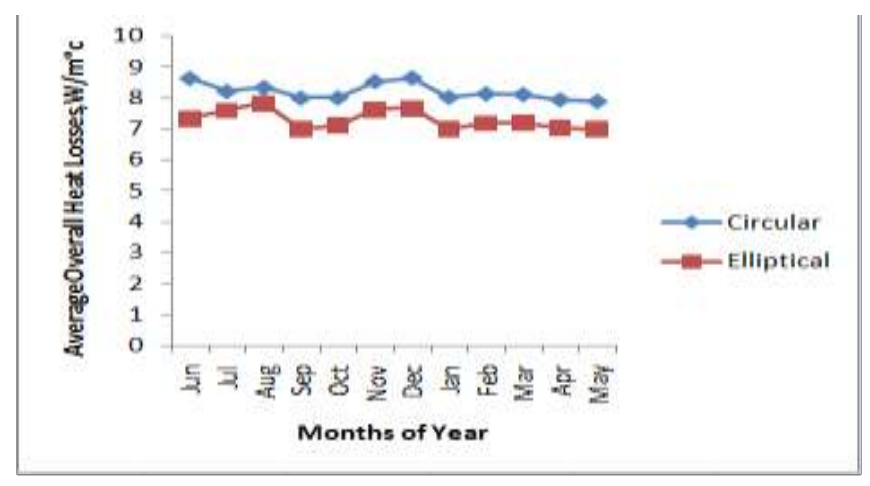

Fig 4. Average Overall heat loss coefficient to Months of Year

Since the enclosed annular area between the absorber tube and the glass tube is maintained in vacuum condition, the thermal losses are reduced to a maximum. Also in the elliptical absorber more vacuum condition is maintained. The overall heat loss is calculated as the average of every month from June 2015 to May 2016 as shown in fig.4.

\subsection{Time of Day Vs Average Useful Heat transfer}

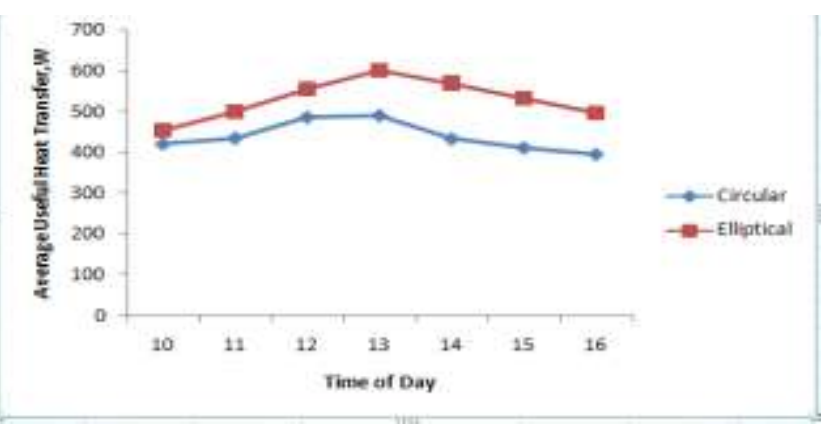

Fig 5 Average Useful heat transfer to the Time of Day

The time of day to the average useful heat transfer is shown in fig.5.Useful heat gained by the collector is based on its heat absorbing surfaces, hence while comparing to the normal absorber the elliptical absorber shows more useful heat transfer rate. 


\subsection{Average Instantaneous efficiency Vs Months of Year}

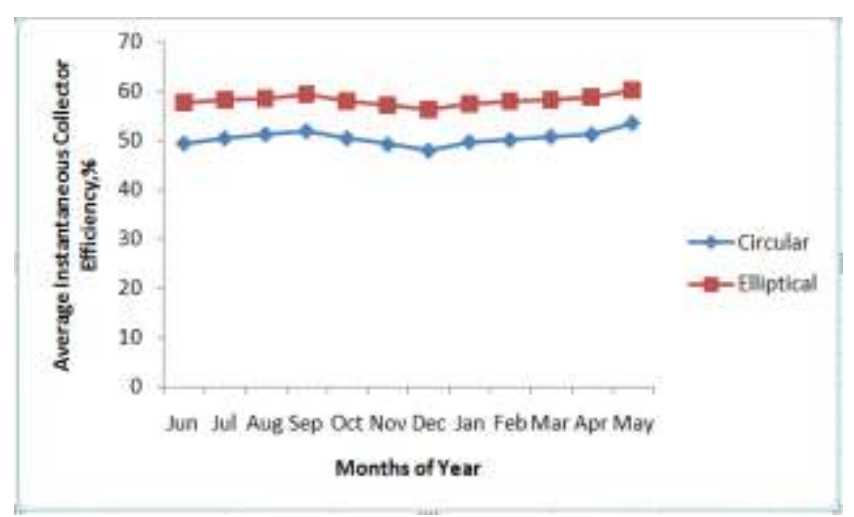

Fig. 6 Average Instantaneous efficiency to the Months of Year

The instantaneous collector efficiency is based on the performance of the collector including heat transfer rate, thermal losses, solar flux absorption capacity ie, the collector aperture area. In this paper the mass flow rate of water is made from $0.016,0.024 \& 0.030 \mathrm{~kg} / \mathrm{s}$. It is also found that the outlet temperature has not been affected much beyond the mass flow rate of about $0.030 \mathrm{~kg} / \mathrm{s}$. Hence from fig. 6 , the instantaneous collector efficiency for the designed and constructed elliptical absorber tube shows better performance in solar parabolic trough collector.

\section{CONCLUSION}

From this study, the solar parabolic trough collector can be employed in industries for heating applications and of course this technique can also be employed for power generation. Since, Chennai in Tamilnadu, India receives proper annual sunny days per year and the solar energy can be harvested for electricity generation. In this paper, the experimental work is carried for a period of 11 months using the normal absorber and newly constructed elliptical absorber. Finally it shows the following results.

1) The instantaneous efficiency has been increased with an average of 9\% for the period of June 2015 to May 2016 with the use of newly designed elliptical absorber tube when compared to normal PTC of circular absorber tube.

2) The outlet temperature of the water is increased, where as the temperature gradient increased considerably.

3) The useful rate of heat transfer received by the collector has been increased to $82.86 \%$ because of the more surface for heat absorption in the elliptical absorber. The receiver temperature is also increased to about $12 \%$ for elliptical absorber when compared to the normal PTC.

4) Comparatively, the heat losses have been reduced because of perfect vacuum condition and proper contact surface of radiation absorption. The thermal losses reduced to about $89.05 \%$ for elliptical absorber tube when compared to the circular absorber tube.

5) The average solar radiation is found to be high for elliptical absorber and recorded as $1002 \mathrm{~W} / \mathrm{m}^{2}$ which is 34 $\mathrm{W} / \mathrm{m}^{2}$ higher than circular absorber at $1 \mathrm{pm}$.

\section{REFERENCES}

[1] A. Fernandez-Garcia, E. Zarza,L. Valenzuela, M. Pérez, "Parabolic-trough solar collectors and their applications" Renewable and Sustainable Energy Reviews, Volume 14, No.7, pp1695-1721,2010

[2] Satish Aher, Atul A. Sagade, N.N. Shinde, P.D.Haridas, "Experimental investigations on black epoxy coated aluminium receiver with FRP parabolic trough collector" IEEE, 978-1-4673-6150-7/13, , Page 291-299,2013

[3] M.I. Roldán , L. Valenzuela, E. Zarza, "Thermal analysis of solar receiver pipes with superheated steam" Applied Energy, volume 1, No.03, ,pp 73-84,2013

[4] K. Ravi Kumar, K.S. Reddy, "Thermal analysis of solar parabolic trough with porous disc receiver" Applied Energy, Volume 86 , pp 1804-1812,2009,

[5] Javier Munoz, Alberto Abanades, "Analysis of internal helically finned tubes for parabolic trough design by CFD tools" Applied Energy, Volume 88 , pp 4139-4149,2011

[6] A. de Risi, M. Milanese, D. Laforgia, "Modelling and optimization of transparent parabolic trough collector based on gas-phase nanofluids" Renewable Energy,Volume 58, pp 134-139,2013

[7] Michael Geyer b, Eckhard Lupfert et al. "EUROTROUGH - Parabolic Trough Collector Developed for Cost Efficient Solar Power Generation" presented at: 11th Int. Symposium on Concentrating Solar Power and Chemical Energy Technologies, September 4-6, , Zurich, Switzerland,2002

[8] A. Valan Arasu, T. Sornakumar " Life cycle cost analysis of new FRP based solar parabolic trough collector hot water generation system” Journal of Zhejiang University SCIENCE A ISSN 1673-565X (Print); ISSN 1862-1775 (Online) www.zju.edu.cn/jzus, www.springerlink.com

6354 | P a g e 
[9] M. Yaghoubi, F. Ahmadi, and M. Bandehee, "Analysis of Heat Losses of Absorber Tubes of Parabolic through Collector of Shiraz (Iran) Solar Power Plant" Journal of Clean Energy Technologies, Vol. 1, No. 1,pp 33-37, 2013

[10] Changfu You , Wei Zhang , Zhiqiang Yin, "Modeling of fluid flow and heat transfer in a trough solar collector" Applied Thermal Engineering, Volume 54,pp 247-254,2013

[11] David H. Lobon , Emilio Baglietto , Loreto Valenzuela , Eduardo Zarza, "Modeling direct steam generation in solar collectors with multiphase CFD" Applied Energy, Volume 113, pp 1338-1348,2014.

[12] A.A. Hachicha, I. Rodriguez , R. Capdevila, A. Oliva, "Heat transfer analysis and numerical simulation of a parabolic trough solar collector", Applied Energy, Volume 111, pp 581-592,2013

[13] N. Naeeni, M. Yaghoubi, "Analysis of wind flow around a parabolic collector (1) fluid flow" Renewable Energy, Volume 32, pp1898-1916,2007

[14] J. Duffie and W. Beckman, "Solar Engineering of Thermal Processes" John Wiley and Sons, New York USA,2006

[15] Soteris A. Kalogirou "A detailed thermal model of a parabolic trough collector receiver Energy" Available online 11 July 2012

[16] D. Yogi Goswami, F.Kreith, J.F. Kreider, (2003) Principals of solar engineering, Taylor and Francis, Philadelphia,USA.

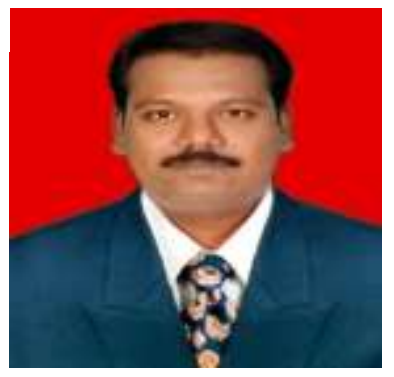

\section{BIOGRAPHY}

Dr.Suresh.R was born to Dr.P. Rajendran and Mrs. T. Rugmoni on 29 May 1977 in Vaithianathapuram, Kottar (P.O), Nagercoil- 629002, Kanniyakumari District, Tamil Nadu, India. He completed his Bachelor Degree in Mechanical Engineering at MEPCO Schlenk Engineering College, Sivakasi under Madurai Kamaraj University in the year 2000. He joined in Madurai Kamaraj University to do his Post Graduate Studies in Master of Business Administration and was awarded with the degree in the year 2003. He joined in Annamalai University, Chidambaram to do his Post Graduate studies in Thermal Power Engineering and was awarded the degree in the year 2005. He joined in Sathyabama University, Chennai to do his Ph.D research in I.C Engines and was awarded the degree in the year 2013.

After his post-graduation, he worked at Udaya School of Engineering from June-2005 to April-2013, Cape Institute of Technology from May-2013 to June-2015, GRT Institute of Engineering and Technology from July-2015 to August-2016 and now presently at Vel Tech High Tech Dr.Rangarajan Dr.Sakunthala Engineering College from August-2016 to Till Date. He has guided several projects in under graduate level and also in post graduate level. He has published number of scientific research papers of which Seven papers have been published in International Journals and three in International Conference proceedings and out of which one paper have been published in IEEE Explore. He has also published three papers in National Journals and four papers in National conference proceedings.

He had submitted three research proposals in SERB out of which two as Principal Co-ordinator and one as Co Principal Co-ordinator. Also, three patents have been filed out of which one as Principal Co-ordinator and two as Co Principal Co-ordinator.

He is been a reviewer for four International Journals, made research tie-up with lot of organizations, having membership in professional bodies, organized lot of Seminars and Conferences etc. His research areas include Internal Combustion Engines, Thermal Engineering, Fuel Chemistry, Alternative Fuels, Energy Engineering. 